\title{
TRAVESTILIDA
}

E MORALIDADES: ANÁLIS EXPERIÊNCIA DO RETORNC INTERIOR PARAIBA 


\section{TRAVESTILIDADE E MORALIDADES: ANÁLISE DA EXPERIÊNCIA DO RETORNO AO INTERIOR PARAIBANO}




\title{
TRAVESTILIDADE E MORALIDADES: ANÁLISE DA EXPERIÊN- CIA DO RETORNO AO INTERIOR PARAIBANO
}

\begin{abstract}
Resumo
O propósito deste artigo é apresentar elementos de uma reflexão etnográfica sobre espaços e dinâmicas de negociação entre processos migratórios, sentidos morais e a aquisição de bens de consumo a partir de uma perspectiva biográfica e de microanálise. A estratégia prioritária para execução da investigação foi o investimento em história de vida, a observação contínua de seu cotidiano através do contato com seus espaços de trabalho, lazer e, quando possível, também os espaços familiares. O mote do artigo são as narrativas sobre a experiência de retorno de uma travesti do interior paraibano após residir na Europa. Natural da cidade de Guarabira no Agreste paraibano, a travesti iniciou seu projeto de migração em 2000 e após constituir um patrimônio considerável, retornou para cidade a natal, onde se consolidou no mercado de serviços de beleza. Em suas narrativas, ela busca avaliar a construção de um projeto e de um patrimônio como parte do processo de negociação para o lugar de retorno, informando sobre aspectos relativos à moral, circulação de bens, produção de pessoas e afetos.
\end{abstract}

Palavras-Chave: Travestilidade, retorno, consumo.

\section{TRAVESTILITY AND MORALITIES: ANALYZING THE EXPE- RIENCE OF RETURN TO THE INTERIOR OF PARAÍBA}

\begin{abstract}
The purpose of this article is to present elements of an ethnographic reflection on spaces and negociation dynamics among migratory processes, moral senses and the acquisition of consumer goods from a biographical perspective and microanalysis. The primary strategy for carrying out the research was the investment in life history, the continuous observation of daily life through contact with spaces of work, leisure and, where possible, the family spaces. The motto of the article is the narrative of the experience of a transvestite returning to the interior of Paraíba after residing in Europe. Born in the city of Guarabira in the Agreste of Paraíba, the transvestite began her immigration project in 2000 and, after constituting a considerable patrimony, she returned to her native city, where she has consolidated in the beauty services market. In her narrative, she seeks to evaluate the construction of a project and heritage as part of the process of negotiation for the place of return, informing about aspects related to morality, circulation of goods, production of people and affections.
\end{abstract}

Keywords: Travestility, return, consumption. 


\section{TRAVESTILIDAD Y MORALIDADES: UN ANÁLISIS DE LA EX- PERIENCIA DE RETORNO AL INTERIOR PARAIBANO}

\section{Resumen}

El propósito de este artículo es presentar elementos de reflexión etnográfica sobre espacios y dinámicas de negociación entre procesos migratorios, sentidos morales y adquisición de bienes de consumo a partir de una perspectiva biográfica y de microanálisis. La estrategia prioritaria para la ejecución de la investigación fue el empleo de la historia de vida y la observación continua de la cotidianidad a través del contacto con los espacios de trabajo, de ocio y, cuando fue posible, de los espacios familiares. El tema del artículo son las narrativas sobre la experiencia de retorno de una travesti del interior paraibano después de residir en Europa. Natural de la ciudad de Guarabira, en la región del Agreste paraibano, la travesti inició su proyecto de migración en el año 2000 y, tras acumular un patrimonio considerable, retornó a su ciudad natal, donde se consolidó en el mercado de servicios de belleza. En sus narrativas, ella busca avalar la construcción de un proyecto y de un patrimonio como parte del proceso de negociación con su lugar de retorno, informando aspectos relativos a la moral, la circulación de bienes, producción de personas y de afectos.

Palabras clave: Travestilidad, retorno, consumo

Endereço do autor para correspondência: Rua Agamenon Lafayete, n. 96. CEP: 58500-000. Cidade: Monteiro. Paraíba - PB 
INTRODUÇÃO: PENSANDO O LUGAR E SUAS POROSIDADES

Pensar sobre sexualidade em regiões interioranas e na experiência da travestilidade no Nordeste, é inevitável deixar de mencionar as pesquisas nos grandes centros urbanos. Não falo isso para destacar essencialidades da "interioridade" (Gontijo, Erick, 2015) como em espaço de interseções, mas para evidenciar que a agenda e os interesses dos cientistas sociais estão, cada vez mais, voltando seus olhos para as potências das sexualidades interioranas e suas constantes porosidades, uma vez que os espaços, por mais longínquos que possam estar do que comumente se entende por centro, estão conectados e em intensa comunicação.

Nesse sentido, a proposta desse artigo é apresentar elementos de uma reflexão etnográfica sobre os espaços no interior paraibano e as dinâmicas de negociação da moralidade nos processos migratórios e os sentidos atribuídos a partir da experiência de retorno de uma travesti paraibana após sua experiência na Europa. Aqui, o principal relevo será para a trajetória de vida de Suy Piovani e como é orquestrado o imaginário dos moradores sobre o seu retorno e permanência em Guarabira, cidade natal da travesti que "deu certo" na Europa.

Guarabira é um dos principais municípios do estado da Paraíba, cuja história é marcada pelo colonialismo lusitano e a religiosidade católica. De acordo com dados do IBGE, em 2016 a população estimada está em 58.529 pessoas. Ela se destaca por ter rotas facilitadas para três capitais: João Pessoa- PB, Recife-PE, Natal- RN e Campina Grande, a segunda maior cidade da Paraíba. O tecido urbano de Guarabira a conforma em uma malha industrializada relativamente ampla, onde é possível observar uma clara simbiose entre o rural e o urbano (Lefebvre, 2001). O destaque no comércio está no setor alimentício com indústria avícola Guaraves, uma das maiores do país, indústria da cachaça e no setor têxtil. Por ser uma região de terras férteis, é notória a grande presença da produção de cana de açúcar e de abacaxi. A cidade também se destaca por ter um dos centros universitários mais antigos do estado, onde funciona o curso de Direito, História, Geografia e outros.

Ao flanar por Guarabira, é possível perceber as marcas do coronelismo em seus casarões com eiras e beiras. A colonização da região data do século XVI, com a forte presença de senhores de engenho, transformados em coronéis e da religiosidade católica com especial atenção para Nossa Senhora da Luz, hoje padroeira da cidade. Estes breves apontamentos, nos possibilita compreender, minimamente, como está traçada a cartografia urbana de Guarabira. E como bem aponta Gilberto Velho (2003) a cidade funciona como um território heterogêneo, pensado como uma forma de administração e controle, assim o que não é brevemente planejado é posto na categoria do "desvio" ao destoar dos padrões considerados normais para o sistema de relações.

Ainda com a perspectiva do desvio, é válido destacar que a região do Agres- 
te, assim como o Litoral Norte paraibano são as regiões do Estado que nos últimos anos têm se notabilizado na mídia local e nacional como espaços "exportadores de travestis", em uma configuração complexa onde ideias relativas ao "tráfico de pessoas" e à "exploração sexual" têm sido acionadas como forma de tornar inteligível a "gravidade" do problema e o interesse do Estado através de ações nas duas margens do Atlântico para controlar os fluxos de meninos gays e travestis migrando para países como Espanha e Itália em busca de trabalho e melhores condições de vida. Isso posto, meu interesse particular diz respeito ao processo de negociação entre moralidades, trocas afetivas, econômicas e avaliação dos vínculos com a família e amigos frente aos resultados obtidos depois de "ir fazer a vida lá fora".

\section{TRAVESTILIDADE E AS MORALIDA- DES NA CONSTITUIÇÃO DOS BENS}

Não sei se a sociedade me aceita ou me atura!

Suy Piovani

A bibliografia em ciências sociais que vem se dedicando, desde os finais dos anos 1970, aos estudos das experiências travestis, tem se organizado como uma produção centrada em dois contextos complementares no que se refere às geografias enquanto lócus de produção de subjetividades travestis. O primeiro diz respeito às travestis e as experiências destas em grandes centros urbanos brasileiros (Oliveira, 1994; Silva, 1996; Kulick, 1998; Benedetti, 2005; Pelúcio,
2009); o segundo eixo por sua vez tem se concentrado nas experiências migratórias, fundamentalmente à Europa através de países como Espanha e Itália (Agnoletti, 2014; Patrício, 2008; Vale, 2005). Ao correlacionar ambos os lócus, as discussões são sobre processos e dinâmicas de transformação corporal, trabalho sexual, violência, cidadania e relação com o Estado, gestão de grupos e regimes de cuidado de si que passa pelo saber médico.

Ao conceber as travestilidades como experiências situacionalmente caracterizadas pelos intensos trânsitos e negociações, pertencimentos corporais, geográficos, de gênero e por vezes identitárias, as reflexões antropológicas e sociológicas têm facultado ainda uma reflexão profunda sobre os efeitos semânticos e experienciais do processo de trânsito enquanto um movimento produtor de diferenças. Essas diferenças dizem respeito não apenas à adjetivação da própria constituição identitária, como analisou Cecília $\mathrm{Pa}$ trício (2008) a respeito da noção de travesti "europea", mas das tensões que marcam as experiências de ir e voltar enquanto experiências articuladas, em especial quando as escalas geográficas em questão apontam para regimes de relação marcados por uma complexidade na forma como as moralidades são acionadas e contrastadas, compondo jogos intricados de produção de sentidos.

Sobre os campos de tensão, Michelle Agnoleti (2014) em sua tese, que trata sobre a transmigração de travestis paraibanas para se integrar ao mercado do sexo internacional, aponta para uma 
reportagem que identifica ser o primeiro capítulo de uma história não concluída sobre a experiência migratória e o considerado "tráfico de pessoas". Vejamos:

"Em 20 de fevereiro de 2005, uma reportagem especial da jornalista Henriqueta Santiago, publicada pelo Jornal Correio da Paraíba, sob o título "Gays voltam ricos da Europa, influenciam e 'exportam' jovens" lançava nos anais da imprensa paraibana o primeiro capítulo de uma história que não conheceu desfecho. Nela, a repórter entrevistou uma travesti de meia idade que hoje é apontada como a chefe de uma quadrilha que traficava jovens homossexuais oriundos de pequenas cidades como Araçagi (17.252 habitantes), Guarabira (57.383), Mulungu (9.750), Baía da Traição (8.561) e Rio Tinto (23.883). Em mais de uma página ilustrada do jornal de maior circulação no estado, essa travesti discorria sobre os caminhos e descaminhos percorridos até que pudesse, através do investimento da renda obtida através do exercício da prostituição, constituir um patrimônio sólido, apresentando-se na época como dona de uma loja de vestidos de luxo localizada na cidade de Florença, na Itália, já não mais prostituta. Ela retornou ao Brasil e adquiriu diversos imóveis, o que, de certa forma, despertou a atenção de jovens travestis desejosas de trilhar a mesma trajetória de sucesso que ela" (Agnoleti, 2014, p. 103).

Os bens como elemento classificatório e de distinção das posições sociais parece ter uma importante centralidade na experiência da migração. Não se trata apenas de sair de um país violento no que diz respeito à experiência da travestilidade, mas de ir ao encontro de um mercado de trabalho que possibilite mobilidade social. Assim sendo, questões relativas à aquisição de bens e condição da moralidade, será apresentado neste artigo, não sobre os ombros da travesti Suy Piovani, mas a partir das suas percepções e uso dos bens em sua vida social.

Vale destacar que nos valores do migrar no contexto do capitalismo tardio, a migração de contingentes humanos para fins de trabalho é um processo caracterizado por dinâmicas flexíveis, como lembra AihwaOng (1999), o que produz por sua vez modos ambivalentes que se relacionam com os sentidos e valores que caracterizam a experiência em sua precariedade. No contexto de uma geopolítica que atribui sentidos distintivos às rotas migratórias, caracterizando alguns processos como mais ou menos prestigiosos frente a outros, ir à Europa ou aos Estados Unidos, capitais simbólicas de um capitalismo materialmente descentralizado - ou mais propriamente, multicentralizado - distingue quem faz parte dessas rotas frente àqueles que migram para outros lugares do Sul Global, por exemplo. Assim, parafraseando Hardt e Negri (2000), o que constitui a Europa como um centro consagrado do processo migratório protagonizado pelas travestis não é seu domínio em termos quantitativos, mas o modo como ele se estabelece como modelo almejado frente a outros processos migratórios.

A experiência na Europa é considerada por muitos um roteiro consagrado, 
espaço de glamour, de construção de uma vida melhor, ainda que por meio de regimes severos e condições de vida muitas vezes indesejáveis. Se por um lado, no processo de transmigração "chegar lá", à Europa, já é um indício de sucesso, por outro lado esse sucesso tende a omitir os diversos entraves e tensões que caracteriza a vida fora de casa, bem como a forma como se articulam espaços, agentes, interesses e agenciamentos que viabilizam tanto ir quanto retornar.

Nesses termos, se mobilidade é um atributo dado para as travestis, ir e vir, sair e voltar, são elementos que as constituem enquanto pessoas e sujeito moral. Assim, o trânsito que configura a experiência migratória é um processo que faz parte da constituição da pessoa das travestis, e justapõe-se a um conjunto mais amplo de experiências e elementos que são as transações econômicas, as avaliações e negociações com a moral e, os processos de transformações corporais. Portanto, uma premissa deste trabalho é que a contiguidade e conectividade desses processos permite uma analítica da travestilidade enquanto processo de múltiplas negociações, sendo a negociação entre e com moralidades frente ao voltar para o lugar de origem meu interesse maior.

A noção de nacionalidade é de suma importância para analisar tanto as estratégias migratórias, quanto as negociações do retorno. Sobre este ponto, a antropóloga Cecília Patrício (2008) passa a analisar a categoria europea para descrever as negociações entre identidades e as distinções existentes entre as travestis que viajam para Europa e as que ficam no Brasil. Sobre esses aspectos, Patrício disserta:

"A marca do gênero e raça é destaque na presença das interlocutoras na Espanha, quando se pensa que travestis brasileiras possuem uma característica distinta de outros grupos migrantes, como também as demais travestis do mundo que se encontram na Espanha tentando fazer a vida. São pessoas que praticam prostituição, e em propaganda afirmam ter um membro viril de maior tamanho que a média. O que remete muito bem características de país que sofreu influências africanas e tem no atributo virilidade e tamanho do membro genital a marca de ser mestiço" (Patrício, 2008, p. 31-32).

Nessa medida, a flexibilização da experiência de trânsito e a inserção das interlocutoras com as quais tive contato, as inserções nos mercados do sexo europeu se caracterizam como um intenso processo de articulação interseccional entre marcadores da diferença social. Relembrando as análises de Adriana Piscitelli a respeito de mulheres cisgêneras ${ }^{2}$ inseridas nos fluxos globais que constituem os mercados transnacionais do sexo e do casamento, as migrantes são afetadas pelas articulações que ocorrem entre as noções atribuídas à sexualidade, gênero, raça, etnicidade e nacionalidade (Piscitelli 2008; 2013). De modo igual, a condição de brasileira, e a corporificação de atributos raciais e cor de pele, a performatividade lida como mais ou menos feminina, o lugar de origem, bem como a corporalidade assumem lugar na forma como o processo migratório pode ser mais 
ou menos bem-sucedido.

$\mathrm{Na}$ outra ponta da experiência do trânsito, a família ocupa um lugar importante, pois organiza as narrativas que incidem sobre processos de abandono, desqualificação, suporte, ou mesmo de exploração. A família assume um sentido plural, advertindo assim às diversas instâncias afetivas, econômicas e de vinculação (biológica e social) que operacionalizam para descrever as relações sociais e afetivas. Essas instâncias encontram-se diluídas, por vezes coincidindo, por vezes estabelecendo mecanismos de hierarquização entre laços afetivos (família do coração), biológicos (família de sangue) e afetivo-biológicos ("família mesmo", "família de verdade") que se traduzem no modo como são interpretadas as relações entre pais, mães, filhos, outros parentes e afins.

Sobre o papel da família nas estratégias de migração do Nordeste brasileiro para outras regiões do país e o retorno, Parry Scott (2014) tem como pressuposto que a maioria dos migrantes foi excluída da força de trabalho no local de origem, ou a transferência da responsabilidade no sustento do grupo doméstico. Ainda que Scott esteja interessado sobre as migrações de famílias nordestinas tradicionais e heterocentradas, é possível ampliar a reflexão sobre o retorno para áreas da sexualidade destoante, pois retornar também tem implicações sentimentais, assim: “voltar por causa de saudades não nega as outras razões, simplesmente reforça a noção de que no Nordeste o migrante de retorno terá redes de relações estabelecidas na qual ele possa reintegrar e retomar uma posição que deixou atrás quando saiu" (Scott, 2014, p. 124).

\section{UM SONHO POSSÍVEL E A RETÓRI- CA DA NEGOCIAÇÃO}

No que diz respeito à saída da travesti Suy Piovani de sua cidade de origem sobre a análise da moralidade, é de suma importância salientar que a antropologia moral não tem nenhum projeto moralizante (Fassin, 2012). Aqui a moralidade é compreendida como um conjunto de valores e princípios não fixos de uma cultura, no qual os indivíduos podem (re)negociar o modo de conduzir-se na sociedade (Foucault, 2012; Oliveira, 2004). Para tanta, ao falar sobre moral, falamos em "produção, veiculação e embate de significados; implica retraçar dinâmicas entre representações, bem como entre os agentes sociais que produzem ou se apropriam de tais representações e das estratégias ou contextos nos quais elas são postas em ação" (Vianna, 2001, p. 24). Dessa forma, ao tratar sobre a negociação das moralidades no retorno da travesti que migrou para a Europa, aponto para as tensões na sociedade em que ela está inserida, considerando as inclinações morais, isso é: pensar sobre moralidades como valores encontradas no interior de culturas concretas e, que não devem ser tomadas como normativas. (Oliveira, 2004).

Como indica Didier Fassin (2012), o problema da "antropologia moral" está na semântica. Diz respeito tanto aos jogos de produção de sentidos que caracterizam a vida humana em sociedade, como também à própria disci- 
plina e de como ela lida com a moral para além de uma ideia sobre "o bem" e o benfeitor; e sua história no que diz respeito às relações entre antropólogos e colonialismos. Fassin prefere usar a terminologia 'antropologia moral' ao invés de 'antropologia da moralidade' por questões ligadas a delimitação do objeto e da reflexividade da disciplina antropológica, nesse sentido, o autor argumenta:

"Não há necessidade em restringir a antropologia moral das configurações locais de normas, valores e emoções: o domínio em estudo e as questões que são levantadas para além das moralidades locais; eles incluem, mas às excedem. E não há necessidade de limitar o seu âmbito a moralidades como entidades discretas separadas das outras esferas da atividade humana: questões morais são incorporadas na substância do social; não é suficiente para analisar os códigos morais ou dilemas éticos como se pudessem ser isolado de questões políticas, religiosas, econômicas ou questões sociais ${ }^{3 "}$ (Fassin, 2012, p. 5).

Nesta perspectiva, a antropologia moral coloca em debate e questiona de que forma são colocadas e acionadas na sociedade as disputas 'não-morais' e como são (re)negociadas com as morais. Com isso, o intuito da antropologia moral é fazer um levantamento da moral no mundo. Ancorando-se em Foucault, o autor enxerga a moral como uma espécie de governamentalidade, uma forma dinâmica e polimorfa de gestão da vida onde se exerce poder sobre o outro e sobre si.

As negociações em torno das morali- dades são processos de experimentação marcados por uma hermenêutica de si, práticas em que se reconhece a agência sobre si mesmo, onde é performatizado a estética da existência e que possibilita a proliferação das várias maneiras de 'ser fiel' consigo. Com isso, Foucault argumenta:

"Para ser dita "moral" uma ação não deve se reduzir a um ato ou a uma série de atos conformes a uma regra, lei ou valor. É verdade que toda ação moral comporta uma relação ao real em que se efetua, e uma relação ao código a que se refere; mas ela implica também uma certa relação a si; essa relação não é simplesmente "consciência de si”, mas constituição de si enquanto "sujeito moral", na qual o indivíduo circunscreve a parte dele mesmo que constitui o objeto dessa prática moral, define sua posição em relação ao preceito que respeita, estabelece para si um certo modo de ser que valerá como realização moral dele mesmo; e, para tal, age sobre si mesmo, procura conhecer-se, controla-se, põe-se à prova, aperfeiçoa-se, transforma-se" (Foucault, 2012, p. 37).

No que tange à experiência migratória, considero de suma importância perceber de que forma a travesti narra suas experiências a partir de concepções moralmente balizadas sobre o mundo e, como também produzem sentido para si, visto que toda moralidade se encontra no âmbito social (Fassin, 2012) e conforma "um jogo complexo de elementos que se compensam, se corrigem, se anulam em certos pontos, permitindo, assim, compromissos ou escapatórias." (Foucault, 2012, p. 33). 
Portanto, a moral produz uma geografia ambivalente entre norma, condução, processos de normalização e compreensão da experiência social. Enquanto mecanismo de governamentalidade, ela é tanto prescritiva quanto negociada, estabelecendo-se assim como um jogo de fato, uma arena onde são avaliadas e negociadas expectativas, poderes, discursos, experiências, ontologias e modos de ser no mundo que cotidianamente estão em conflitos. As moralidades são, em última instância, espaços dinâmicos e ágeis de produção de sentidos para as ações socialmente percebidas.

A moral, assim como a cultura, são invenções nas quais o espaço, tempo, gênero, etnia e condições sociais são lugares de interseção. Dessa forma, como indica Judith Butler: "mesmo que a moral forneça um conjunto de regras que produz um sujeito em sua inteligibilidade, ele não deixa de ser um conjunto de normas e regras que um sujeito deve negociar de maneira vital e reflexiva" (Butler, 2015, p. 21). Portanto, ao negociar a moralidade do retorno, Suy Piovani engendra atividades sobre si e negocia a maneira de transitar entre a casa do grupo familiar, a rua, o corpo, a sociabilidade e todos os trânsitos possíveis que compõem as transformações na constituição da pessoa travesti, que também tece para si regras e valores de interdição, transgressão e resistência.

E sobre as formas de negociações do retorno, chego ao ponto máximo desse artigo, onde apresentarei a travesti Suy Piovani e as variadas formas de percepção e construção da realida- de social, no qual os bens e serviços parecem redesenhar a experiência $d a$ sociabilidade. Nesse sentido, os bens podem ser considerados enigmáticos, pois através deles o sujeito pode tomar lugares diferenciados na sociedade que faz parte. Como indica Mary Douglas e Baron Isherwood: "os bens são neutros, seus usos são sociais; podem ser usados como cercas ou como pontes" (Douglas, Isherwood, 2004, p. 36). Os bens, não raro, são considerados como uma espécie de comunicação, ou seja, a parte visível da cultura, com as quais as pessoas tornam inteligíveis suas identidades e estabelecem relações sociais. Nesse sentido, os bens não são meramente uma forma de satisfação pessoal a fim de suprir os próprios desejos, os bens são, sobretudo, para serem trocados, doados, guardados, suprirem obrigações sociais e combater a pobreza (Godelier, 2001; Douglas, Isherwood, 2004; Appadurai, 2008; Miller, 2004).

$\mathrm{Na}$ vida social da travesti Suy, a busca por melhores condições materiais de vida, foi a principal razão de sua migração. Ela residiu na Europa entre os anos de 2000 e 2009, neste período em uma das visitas aos seus familiares, Suy fez parte de uma campanha do governo da Paraíba contra a homofobia e a transfobia. Vestida em uma camiseta com a frase: "Tire o respeito do armário" ela posou para cartazes espalhados em vários cantos do Estado, na ocasião ela também concedeu entrevista para a Colmeia em 2006, um editorial do Movimento Espírito Lilás da cidade de João Pessoa. Considero esta entrevista emblemática. Na reportagem Suy é apresentada da seguinte maneira: 
"O Piovani vem de Luana, atriz de quem Suy é fã e tiete. Ela tem 26 anos, é natural de Guarabira, onde trabalhou nos últimos anos como cabeleireira. Suy sabe o que quer. Inteligente, já entendeu que não vai conseguir fácil. Consciente da sociedade preconceituosa e excludente em que vive ela sabe que ninguém vai lhe dar o que deseja facilmente. Só pode contar consigo mesma. No Brasil travesti não é tratado como um cidadão comum, não tem direitos. Foi para Itália buscar seu futuro e arrastá-lo até onde quer. Quer voltar à Guarabira, ter sua própria casa e seu salão, quer ser patroa" (A colmeia, 2006).

Este trecho traz elementos importantes para reflexão, é claramente um texto de posição política do movimento LGBT da Paraíba. Nele, o autor coloca Suy na posição de subalternidade, onde se estabelece um efeito no qual a travesti "não é tratado como um cidadão comum", uma cidadania desqualificada, uma subcidadania em virtude da travestilidade. No texto do editorial $A$ colmeia, Suy na condição de desviante da norma, é posta como alguém desprovida de direitos e que só poderia contar consigo mesma, onde migrar para Itália é um projeto de ascensão e de inserção em uma posição melhor no local de origem, seja este local a "cidade" onde havia nascido, ou outro aonde viesse estabelecer residência. Nesse sentido, migrar é à possibilidade de uma vida melhor, afastada dessa condição secundarizada de existência onde ela é colocada no texto.

$\mathrm{Na}$ reportagem, ir para Itália, além de ser mais bem remunerada na presta- ção de serviços, é uma espécie de fuga da violência da sociedade brasileira e seus preconceitos, já o retorno na experiência de Suy está traçado para ser glorioso a partir da aquisição de bens. A inserção social transforma-se em um processo de mobilidade dentro de um sistema de valorações onde a presença é analisada a partir da possibilidade de consumir e investir, um processo mediado pelo capital e pelo agenciamento financeiro que o sujeito pode produzir, desse modo, a realização pessoal se encontra no consumo. No entanto, é útil para a análise antropológica não esquecer "que as mercadorias são boas para comer, vestir, e abrigar; esqueçamos sua utilidade e tentemos em seu lugar a ideia de que as mercadorias são boas para pensar: tratemo-las como um meio não verbal para a faculdade humana de criar" (Douglas, Isherwoord, 2004, p. 108). Nesse sentido, as mercadorias estabelecem rotas e modos de vida que o tempo jamais apagará.

Em outro momento da entrevista para A colmeia, Suy fala sobre a melhor parte de viver e trabalhar na Europa e aconselha outras travestis. Duas coisas boas se destacaram sobre a experiência da travesti em território europeu. A primeira foi o dinheiro que conseguiu guardar, a segunda está ligada ao modo considerado respeitoso que era tratada. Na Itália ela era chamada de 'donna' e senhora. No Brasil, ela considera que a sociedade é preconceituosa e trata mal as travestis. $\mathrm{Na}$ entrevista, Suy sugere também que outras travestis perseverassem em prol dos seus objetivos e buscassem investir em imóveis e no comércio. Vejamos o que ela diz: 
"Tem que ter um imóvel, montar uma loja, um comércio, um salão. Tudo é fase como a lua: quando é cheia é cheia, mas depois que mingua, já era. Tem que mostrar que a gente é trabalhadora, que tem alguma coisa. Porque no Brasil você vale o que tem. Tem que lutar e sofre para no final da vida ter do que viver" (A colmeia, 2006).

Perseverante em seus objetivos, Suy é referência para outras travestis, pois é considerada alguém que "tem cabeça" e que "soube investir". Em suas narrativas, Suy se coloca como alguém que se difere de boa parte da trajetória de outras travestis. Ela se posiciona, na medida do possível, como uma pessoa destemida, plena de desejos e que sempre se projetou para o mundo da forma que desejava. Ao falar sobre a exposição da própria experiência da sexualidade, Suy disserta:

" $\mathrm{Na}$ verdade, não é que eu fui corajosa, corajosa é quando você tem medo e cria uma coragem, né isso? E o meu não, foi tudo espontâneo, eu já assumi porque eu não queria sabe de nada, não queria saber de mãe, de pai, de família, de vizinhos, que todos se lascassem, eu queria lá saber... foi espontâneo! Foi de mim. Eu nunca tive medo dessas coisas não. Eu não queria saber o que vai ser, eu acho que por isso deu certo. Porque o medo ele bloqueia muitas coisas. Às vezes você vai fazer uma coisa, vai até um comércio, bota um comércio e tá com medo: "será que vai dar?", aí já começa tudo negativo, aí já quebra. E eu nunca tive medo! Que se danasse, pai, mãe, vizinho, amigo, colégio, professora... Eu quero saber de mim, por quê?
Porque eu gosto de ser feliz, eu procuro a felicidade e a felicidade está dentro de mim, eu tenho que botar ela pra fora, se eu não colocar ela pra fora, eu vou ser o quê? Infeliz! Vou carregar aquela mágoa... como eu já tive amigos meus, pelo fato de serem gays e não assumiu com vergonha ou com medo do pai, da mãe, do irmão... Acabaram se suicidando!"

A história de vida de Suy está repleta de várias vidas: amigos, parceiros, vizinhos, clientes e, sobretudo, familiares. É a família que nos diferencia do mundo animal e estrutura a sociedade, no entanto, família não é apenas uma unidade biológica; ela também se constitui por afinidade (Lévi-Strauss, 1980). Ao fundamentar o social, a família contribui para formação da pessoa, por essa razão, ao narrar a própria história de vida, Suy destaca a vontade de ser feliz, mesmo que isso causasse sofrimento e vergonha aos seus parentes. Ela não quis que sua trajetória fosse parecida com a dos amigos que cometeram suicídio por ter medo e vergonha de vivenciar a travestilidade e homossexualidade em público.

Suy sempre se sentiu pertencer ao gênero feminino, gosta de ser tratada sempre no feminino e mesmo sendo conhecida e reconhecida como travesti, se autodeclara pertencente à categoria transgênero, esse tipo de denominação é comum entre as travestis brasileiras que moraram na Europa, isso ocorre porque a categoria travesti é tipicamente brasileira (Kulick, 1998), e muitas vezes circunscrita a um universo simbólico e de classe ao qual não se pretende vincular. Ao ter contato com pessoas 
trans em outro continente, muitas travestis passam a se autodeclarar como transgênero ou transexual. Para Suy:

"Por mais que a minha voz seja masculinizada, quando você chega perto de mim ou se eu passo num canto, você vê corpo de mulher, você vê jeito de mulher, você vê a fisionomia de mulher! Então como é que eu vou ver uma mulher e chamar ela de ele? Só fez nascer homem, porque quando é criança, né?! A gente não sabe definir. É como a minha amiga disse: "Ah, nasceu! Foi homem ou mulher?" [respondo] Sei não mulher, só sei depois que crescer, depois que crescer eu vou saber se é homem ou se é mulher, entendeu? Então eu gosto de ser chamada sempre no feminino".

Guarabirense, Suy considerou ter vivido sua infância de maneira "normal', diferente de alguns de seus amigos, diz não ter sofrido essa "história de bullying". Relata que nunca chegou em casa chorando pelo fato de ser gay, mas que haviam sempre as consideradas "brincadeirazinhas", mas não identificava esses atos como bullying ou homofobia. Ela acrescenta:

"A minha infância foi bem normal, eu brincava com menino, brincava com meninas, mas me identificava mesmo era com as meninas porque as brincadeiras era academia, era bambolê, também tinha o pique-esconde, toca! Brincar de toca. Eu brincava com os meninos de bandeirinha, eu... Baleada. Era os meninos contra as meninas. Eu tive uma infância maravilhosa, não tenho do que reclamar, não!"

As brincadeiras, em algumas ocasiões, fazem parte de um sistema lúdico de inicialização e manutenção da sexualidade de jovens e adultos (Guerra, 2015), mas no caso de Suy, o encontro com o desejo, muitas vezes considerado clandestino, ocorreu quando ela fazia catecismo e se apaixonou pelo seu colega de turma. Ela o descreve como "lindo", dono de olhos verdes, cabelo bem cortado, pele branca e que lhe despertou atenção, diferente das meninas para as quais ela não se interessava para além da amizade. No que diz respeito à primeira experiência sexual com rapazes, a travesti não tem boas recordações, pois como todos eram adolescentes, desconheciam as performances para fazer sexo prazeroso. Vejamos:

"Eu mesmo vim descobrir, saber o que era sexo mesmo, depois dos dezoito anos, porque eu já passei a me relacionar com pessoas mais maduras. Eu já passei a amar, passei a gostar, a desejar... Nessa época eu pude saber o que realmente era uma transa amorosa (risos)".

As práticas sexuais, assim como as roupas é uma composição quase indispensável para a constituição da identidade do indivíduo, especialmente na experiência travesti. Ainda criança, Suy usava roupas indicadas para o gênero masculino, isso não lhe causava embaraços, pois se tratava de uma relação ligada à geração. Sobre este período a travesti descreve:

"Nunca me incomodou quando eu era criança. Eu usava roupa masculina, era o meu pai e minha mãe que comprava, mas eu sempre gostava de usar o que eu queria. O sapato eu que tinha que escolher, por mais que fosse masculino, mas tinha que 
ser do meu jeito. A camisa, a calça... e eles faziam o meu gosto!"

Suy foi criada pelos avós maternos, sua mãe sofreu depressão pós-parto e passou a morar em Natal, deixando-a para ser criada pelos avós, os quais ela chama carinhosamente de pai e mãe. Seu avô/pai era marceneiro e, desde os 12 anos, Suy trabalhava com os parentes: ela limpava o pó da serraria, lixava e pintava as madeiras, também era sua tarefa separar as lenhas que eram vendidas, transformadas em móveis ou queimadas. Quando começou a receber o próprio dinheiro, passou a ter liberdade para comprar roupas mais femininas. Aos catorze começou a deixar o cabelo crescer, passou a usar baby look e calças mais coladas ao corpo. Nesse momento de transição, Suy diz não ter sido repreendida pelos pais, mas que sua avó demonstrava preocupação sobre as possíveis violências que o neto poderia sofrer. Sobre a família:

"Eles nunca me disseram nada! Só a minha avó que tinha medo do que o meu avó ia falar, medo do que o povo da rua ia falar sobre a história de zombar e debochar sobre ter um neto ou um filho gay. $\mathrm{Na}$ verdade foi ela quem sofreu mais bullying do que eu, porque a vizinha ficava dizendo assim: "É desse jeito porque os pais querem, porque os pais aceita, porque se fosse meu filho eu metia o pau..."”."

$\mathrm{Na}$ vida em sociedade muitas vezes os vizinhos fazem o papel de observador e agente de punição do que consideram desvio da norma. Como bem coloca Ana Claudia Marques (2002, p. 54): "os vizinhos constatam e assumem comportamentos por ve- zes ritualizados; não podem evitar sua condição de árbitro ou instrumento, tal como tampouco parece possível evitar a condição de vítima ou agressor." Neste caso, podemos verificar a tensão social e moral provocada pela vizinha dos avós de Suy, isso ocorre porque a sexualidade destoante do jovem gay, de certa forma, afeta a honra da família, especialmente a honra masculina que está ligada diretamente a virilidade (Fonseca, 2004). Ao escapar da normatividade, na concepção da vizinha, Suy deveria ser agredida pelos avós até começar a se comportar da maneira como um homem socialmente construído deve ser: másculo e viril, e para tanto, qualquer comportamento que fugisse a esse padrão deveria ser punido. Por essa razão, chega a causar estranheza a travesti da ênfase nas palavras: "Nunca apanhei por isso! Nunca na vida, nunca!' E acrescenta: "nunca fui expulsa de casa, ninguém nunca me colocou pra fora pelo fato de eu me assumir. Lógico que ela ficon triste, mas falar: você vai sair de casa, porque você é a vergonha da familia...".

Suy não foi expulsa de casa, mas tinha forte vontade de morar em uma cidade maior e a mais próxima era João Pessoa, a capital. Para ela, todo gay quer ter acesso a uma boate e conhecer a vida na cidade grande. Vejamos a explicação:

"Por quê? Porque interior não tem nada, até hoje não tem nada. Então, eu fiz uma amizade em João Pessoa com uma cabelereira amiga minha. Pelo fato de já ter me assumido em casa, mas meu avô nunca disse nada... Mesmo assim eu queria sair de casa, eu queria ganhar o mundo, porque eu achava que aqui 
era pequenininho. Eu queria uma boate, eu queria dançar, eu queria ver o mundo, queria ver show de transformista, queria ver show de travesti. Eu via no Globo Repórter [programa de TV] a vida noturna de São Paulo e Rio. Eu queria poder ir, mas como eu era uma criança de catorze anos não dava... Aí, tive a ideia de falar para aos meus amigos lá em João Pessoa que eu tinha sido expulsa de casa pelo fato de ter me assumido. Eu que menti! (risos) Eu disse: "eu não tenho onde morar, o que eu faço? Vocês me aceita aí?" Uma cabelereira em Bayeux me aceitou no salão dela e eu trabalhava lá, mas só pelo fato de estar em João Pessoa, porque eu queria morar em João Pessoa, pra poder ir à boate que antigamente era: The $X$, Notório, ali na Diogo Velho... A outra era na praia, a boate de Jane. Fiquei pouco tempo, só seis meses. Aí, como eu nunca fui expulsa de casa, né? podia voltar a hora que queria, só que eu menti, porque onde eu chegasse contando todo mundo ia acreditar, porque isso é normal, né?"

Quando Suy diz: "99\% é expulsa de casa, então se eu fosse mais uma, o povo jamais ia dizer que era mentira minha?', temos elementos para pensar as articulações entre a memória e o possível; o espaço de lembrar e de criatividade que é a própria narrativa e no modo como se desenham as linhas de fuga na escritura social, pois a travesti se inventa e reinventa para existir e vivenciar o prazer de estar no mundo em uma espécie de abjeção e desejo (Pelúcio, 2009). Para Deleuze \&Parnet (1998, p. 36) "uma minoria nunca existe pronta, ela só se constitui sobre linhas de fuga que são tanto maneiras de avançar quanto de atacar." Assim, uma forma de resistência social traçada por Suy está ligada ao acúmulo e capitalização dos bens. As casas, o comércio e o lugar que estes conferem a ela na lógica da cidade são seus domínios sobre o mundo, a forma como ela se vê inserida e negocia seus trânsitos já residindo em Guarabira. Os bens são vistos por ela como a objetificação da possibilidade de tolerância e avanço, por essa razão, quando regressou da sua primeira aventura na cidade grande, não retornou para casa dos pais, foi para casa de outro cabelereiro em Guarabira e logo depois montou seu próprio negócio.

O processo de transformação corporal e de trânsito é percebido por Suy como um momento de avaliação sobre as experiências que motivam sua existência, sobre seus desejos e vontades e sobre as próprias possibilidades dos lugares em que habita. Dessa forma, o interior em uma lógica de lazer e sociabilidade que Suy buscava, é o lugar da falta, é onde "não tem nada", e a cidade grande é o espaço de variedade e de opções que logo se esgotam e tensionam a demanda por novas rotas, novos lugares, novas pessoas e experiências no mundo.

Voltar para casa era um processo de restabelecimento dos laços afetivos, reencontro viabilizado pela relação que Suy mantinha com a família e com a possibilidade de retorno quando necessário ou possível. As relações de Suy com sua família não eram sempre harmônicas e pacíficas, contudo, a elasticidade na qual havia sido estabe- 
lecida possibilitava esses progressivos e constantes movimentos de retorno que executava sempre no intervalo entre viagens ou entre temporadas. Ao retornar trazia histórias, presentes, investia e transformava a forma como seus amigos, parentes e vizinhos viam a travesti (ou transgênero) que havia saído da cidade para fazer a vida.

Suy passou a infância no bairro periférico de Guarabira, o Nordeste, localizado às margens do perímetro urbano da cidade, longe da maior parte das ofertas de serviços e comércio que a cidade dispõe. Saiu de lá para viajar para Europa, lugar onde conseguiu recursos suficientes para adquirir imóveis em algumas partes da cidade e a casa onde mora com os pais (avós) em um bairro de classe média. A travesti descreve a relação com os familiares de maneira amistosa e pouco conflituosa. Ela mantém contato com a mãe biológica que reside em Natal desde a depressão pós-parto; lá também moraram as suas três irmãs e, seu único irmão mora em Guarabira. Suy paga todas as despesas com educação e bens de consumo de uma sobrinha em particular, por ela percebida como uma filha e da qual "faz todos os gostos".

A travesti se dá bem com os familiares, exceto um tio materno que é gay e mora no Rio de Janeiro, mas de acordo com Suy ele só tem implicância com ela, porque ele também havia migrado para um grande centro urbano e não conseguiu tanto sucesso quanto ela. Suy explica:

"Ele tem esse negócio comigo, porque eu me dei bem na vida... E ele, esses anos todos, não tem nada, isso gera uma síndrome de inferioridade. Ele veio há seis anos aqui em Guarabira e fez a maior confusão, disse que se sentiu humilhado na minha casa. Eu não podia dizer nada, que ele já falava que eu queria humilhar... Aí teve uma hora que eu disse: "Meu filho você tá com problema! Você tem que ir pro psicólogo ou se não um psiquiatra. Eu não posso nem abrir a boca?’”'.

Em outro trecho da nossa conversa, ainda sobre o tio, filho dos seus avós e pais de criação:

"A gente percebia dentro dele, pelo comportamento dele, que ele se sentia mal em me ver bem... cuidando da mãe dele, cuidando do pai dele e cuidando da família dele. Zelando e cuidando tudo direitinho. Ele se sentiu mal, ou talvez ele quisesse fazer isso, mas nunca pôde...".

"E eu tenho culpa?" Questiona-se Suy sobre o comportamento e possíveis frustações do tio. Ele é a única pessoa da família que ela tem declaradamente desafeto. Nas avaliações de Suy, esse desafeto é "recalque", "despeito", e "inve$j a$ ”, enfim, avaliações que são resultantes das experiências e resultados que ambos tiveram em seus projetos de sair de Guarabira - e consequentemente na possibilidade de voltar. Voltar para Suy era uma possibilidade existente em virtude do capital acumulado e da possibilidade de produzir para si um lugar "melhor" na cidade, de ter um salão, várias casas, de ser uma pessoa respeitada em uma sociedade onde o consumo e as posses permitem esse tipo de "espaço de ambivalência". O despeito do tio começou a partir do 
momento que ela foi morar na Itália e passou a construir muitas coisas, assim ela acredita que o tio não tenha ficado feliz com os resultados de sua migração e acrescenta: "e sobre o resto, me dou bem com todo mundo", em especial a sobrinha, a qual chama de filha. Ela tem 8 anos e é a mais amada entre os sete sobrinhos. A sobrinha querida chegou a morar 2 anos com Suy em Guarabira, mas sua irmã não se adaptou ao lugar e voltou para Natal, mas Suy vai periodicamente visitá-las. Sobre a narrativa da sobrinha, conclui dizendo: "ela é a minha vida!".

Ir para Europa, foi uma maneira de Suy traçar suas linhas de fuga, ou como sugere Deleuze, de perceber-se num espaço de experimentação-vida, onde não existe nem passado nem futuro, apenas projeções, isso é: "programas de vida, sempre modificados à medida que se fazem, traídos à medida que se aprofundam, como riachos que desfilam ou canais que se distribuem para que corra um fluxo" (Deleuze \& Parnet. 1998 p. 39). As linhas estão em todos os lugares, linhas de fugas contínuas e permanentes.

São estes traços que atribuem sentido à existência de Suy, em uma busca constante por aceitação e tolerância. Ir para Europa contribuiu para que ela consolidasse algo que havia posto em movimento, uma vida economicamente estável e confortável. Diz ela:

“Quando eu resolvi ir pra Itália... eu já tinha a minha própria casa, eu já tinha a minha clientela, eu já era cabelereiro, eu já tinha... Eu já sobrevivia com o meu próprio dinheiro, eu já ajudava a minha família, não ajudava como hoje, não tinha uma casa como eu tenho hoje, mas eu já tinha, eu já possuía. Então assim... A minha família não me vê como um gay, como uma travesti, como homossexual... Me via como profissional porque desde dos catorze, desde dos quinze anos eu já era profissional".

Ao seguir analisando a própria conjuntura social, econômica e familiar, Suy disserta:

"Eu acho que existe uma diferença muito grande entre os homossexuais, as gays, lésbicas, LGBT... Eu acho que tem um diferencial grande. Às vezes discriminam você não pela sua orientação sexual, é o que você é também, porque todo mundo tem o direito de ser o que é, mas também tem que ter a profissão que deseja e muitos não querem profissão... Querem depender de pai e mãe, da família e fica disturbando a família, extorquindo, querendo dinheiro, chantageando... ser uma vergonha da família!"

Suy critica as pessoas de sexualidade dissidente que não querem ter uma profissão e ficam dependendo dos familiares. Assim, as moralidades enquanto sistemas de sentidos, na forma acionada por Suy remetem também à dissidência como uma falta de engajamento produtivo em uma economia orientada para o sucesso e para o ganho. Em última instância, para Suy o preconceito também está entrelaçado à falta de bens. Vejamos o exemplo que ela usou para ilustrar seu argumento:

"Pronto, eu tenho uma amiga, que ave Maria! Ela tá com quarenta anos e nunca construiu nada e a mãe até que sustenta. Tem um ma- 
rido dentro de casa e a mãe vive morrendo de desgosto. Quer dizer? É pelo fato de ser travesti... Não é! É pelo fato de quarenta anos, ser a vergonha da família porque até hoje vive nas asas da mãe, só come se a mãe der, não tem um salão, não se interessa!"

Continua:

"Então eu vejo dessa forma. Eu acho assim: se você é jovem ou até uma certa idade e você escolhe assumir mesmo a sua homossexualidade, você tem que ter uma profissão e ser independente, porque a história é outra. Todo mundo vai lhe amar, tomo mundo vai lhe respeitar, todo mundo vai lhe aceitar. Agora você assumir a sua orientação sexual e depender de pai e mãe... Aí minha filha... Aí você vai comer um dobrado, viu?"

Assumir-se é um movimento que, na retórica de Suy, devem vir acompanhados de um movimento de autonomização da vida. A via para construção da autonomia passa pelo engajamento no mundo do mercado e do trabalho, o mundo da produção de sentidos sociais através do consumo e no consumo. Aqui, o consumo é um espaço de inteligibilidade, uma arena moral para construção de avaliações sobre o mérito e a validade de algumas experiências, expectativas e exigências.

A impressão de Suy sobre moralidade e vergonha nos remete a concepção de projeto, emoção e orientação de Gilberto Velho (2008) elementos usados para analisar as distinções das sociedades complexas e que estão diretamente ligados a um projeto de organização social que visa prestigiar a imagem cons- truída por meio das relações e vínculos sociais - nesse caso mediados pelo trabalho e pelo dinheiro. Contudo, a relação estabelecida por Suy é uma relação que borra um cerceamento estreito entre o entendimento de profissão como algo meramente mercantilista ou a busca por uma expressiva ascensão social. A autonomia e a independência repercutem uma noção de indivíduo como capacidade de autogestão, onde não há interferência da família, ou seja: o domínio de si no que diz respeito aos bens e serviços e a capacidade de trocas entre os familiares através da ajuda.

Quando a travesti tem uma profissão adquire prestígio e afeto, nas palavras simples de Suy: "Todo mundo vai lhe amar, todo mundo vai lhe respeitar, todo mundo vai lhe aceitar". Nesse sentido, a profissão é uma forma eficaz de comunicação, um projeto individual construído "em função de experiências sócio-culturais de um código de vivências e interações interpretadas" (Velho, 2008, p. 28). Por essa razão, Suy conduziu sua vida em prol da profissionalização, faz cursos periodicamente para aperfeiçoar e atualizar as tendências. Esta motivação vem do desejo de sempre proporcionar algo novo para sua clientela, que também pode funcionar como uma forma de linguagem pública de um trabalho bem feito e modernizado. Nesse sentido, Suy busca fazer a diferença na oferta de trabalho, não por acaso, ela é a única a ter um serviço exclusivo e considerado de alto padrão para as noivas.

Constata-se que os bens de consumo são parte essencial da vida em sociedade. Como indica o antropólogo Daniel 
Miller (2007), pensar o consumo como parte da cultura material é fundamental para compreensão das relações sociais, assim o consumo não deve ser percebido "como um perigo" ou "antissocial", mas em certa medida como abolição da pobreza, algo que muitas vezes não é levado em consideração em virtude no moralismo que cerca as teorias do consumo. Miller defende que o consumo contribui para amenizar as desigualdades sociais e que os bens materiais fazem parte do sistema de comunicação.

Nesse sentido, para o autor é necessário admitir "que nós vivemos num tempo no qual a maior parte do sofrimento humano é ainda o resultado direto da falta de bens." (Miller, 2007, p. 38). A busca por bens impulsiona a saída de milhares de pessoas do lugar de origem, pois é através deles que muitas pessoas se constituem como sujeito de direito e de prestígio perante a sociedade. Por isso, é válido destacar o conselho que Suy deixa para outras travestis, "tem que ter um imóvel, montar uma loja, um comércio, um salão." Por vezes a materialidade está ligada a constituição de pessoa, pois não é de forma deliberada que a Suy considera que "no Brasil você vale o que tem?'.

A perspectiva dos bens como sistema de comunicação, fica evidente na fala de Suy, quando diz: "fui obrigada a construir esse salão." Ela sugere uma ritualização dos objetos que fazem parte da vida privada, já que ela havia passado 9 anos na Europa, ela teria que construir um salão de beleza requintado para a região, com serviços ainda não ofertados, por essa razão, Suy sentiu a necessidade de dar satisfação para a sociedade que faz parte através da aquisição dos bens. De todo modo, o consumo dos bens diz respeito a uma tentativa de adquirir uma vida melhor, pois a maioria dos migrantes nordestinos, no qual Suy faz parte, experimentam ou experimentaram da pobreza de bens de consumo e, migrar abre a possibilidade para melhores condições materiais a fim de combater a desigualdade, aumentar o padrão de vida (Miller, 2004) e, consequentemente, obter respeito ou tolerância para a condição de sexualidade destoante.

\section{CONSIDERAÇÕES FINAIS}

No espaço do capitalismo tardio global, as sociedades ocidentais têm enxergado a ascensão social como um espaço de ascensão capital-financeira, algo positivo e almejado, pelas classes baixas e médias. Ter influência e respeito nessas sociedades, muitas vezes está entrelaçado aos bens capitalizados no decorrer da vida, algo que Suy contempla com veemência em suas narrativas. Assim, no contexto das sociedades contemporâneas, o exercício do poder é simultaneamente diluído através de relações cotidianas e micropolíticas onde o poder se manifesta de maneira capilar e polimorfa, quanto é também organizado em função das distinções e dinâmicas entre classe, prestígio e, particularmente no caso do Brasil, raça-cor de pele e gênero.

É dessa maneira que um Estado masculino incide sobre as vidas de mulheres e travestis através de dispositivos violentos, ao mesmo tempo em que se 
serve de seus corpos como fonte de prazer e fruição precarizados através do cerceamento de direitos e garantias sociais básicas. É ainda nesse contexto que, banhando-se nas próprias estratégias da sociedade hegemônica, se percebe os processos de mobilidade espacial produzidos por travestis, como projetos sociais de relocação em uma dinâmica de capital e de prestígio. Ao migrar Suy e demais travestis estabelecem projetos de vida que, através do trabalho sexual, da militância, do casamento, de um novo cenário, possam construir e inserir-se em espaços relacionais onde suas vidas sejam "melhores", longe da discriminação, da violência que circunscreve a narrativa convencional sobre as travestilidade no Brasil.

Com isso, os movimentos migratórios são projetos de transformação da vida, projetos que têm como fim a busca por melhores condições de vida e de realização pessoal que se estabelecem através das experiências com outras pessoas, lugares e línguas. Migrar é também um intenso investimento numa economia moral marcada pela dinâmica e pela potência das negociações sociais. Por isso, a inserção nos espaços doméstico e familiar faz parte de um circuito de trocas afetivas, que ocorre também através dos bens e recursos capitalizados na experiência de morar e trabalhar fora.

Nesse sentido, os bens adquiridos ao migrar, não são apenas bens de consumo em sua materialidade, é a expressão de ter dado certo e de poder ser respeitada e ter uma velhice com o mínimo de dignidade, ou mesmo "tolerada", como expressou Suy. Dessa maneira, o salão de beleza, as casas alugadas, o carro, os presentes dados para os familiares, a casa própria, as mensalidades da escola particular da sobrinha tudo isso é a materialização do sacrifício realizado em outro país, onde o principal objetivo era o de eliminar a pobreza e adquirir capital econômico e simbólico.

Por fim, retornar para a casa, para próximo do ambiente doméstico e familiar a partir do qual o processo migratório iniciou-se, é também um processo de reinvenção de si e avaliação da própria trajetória. É um processo de negociação com as moralidades no qual a própria trajetória de vida, geográfica e os efeitos dos deslocamentos operados incidem como espaços de interrogação. Em um contexto fortemente caracterizado pelo domínio de uma ordem social comprometida com um ordenamento compulsório e heterossexual das experiências de corpo e gênero (Butler, 2003), fazer sucesso na vida lá fora e voltar como uma pessoa "de bens" é uma estratégia para reinserir-se no espaço doméstico e comunitário-familiar como uma pessoa "de bem", expressando a maneira como projetos sociais e mecanismos de produção de sentido se conectam e confluem.

\section{NOTAS}

${ }^{1}$ Cecília Patrício mantém a grafia como é falada na Espanha.

${ }^{2}$ São pessoas em consonância entre o sexo de nascença e o gênero.

${ }^{3}$ Trecho literal: There is no necessity in 
confining moral anthropology to local configurations of norms, values, and emotions: the domain under study and the issues that are raised go far beyond local moralities; they include but exceed them. And there is no need to limit its scope to moralities as discrete entities separated from the other spheres of human activities: moral questions are embedded in the substance of the social; it is not sufficient to analyze moral codes or ethical dilemmas as if they could be isolated from political, religious, economic, or social issues (Fas$\sin , 2012$, p. 5).

\section{REFERÊNCIAS}

Agnoleti, Michelle Barbosa. 2014. A transmigração no espaço, no corpo e na subjetividade: deslocamentos de fronteiras na experiência de travestis paraibanas na Itália. Tese de Doutorado. Departamento de Sociologia. Universidade Federal da Paraíba, BRA.

Benedetti, Marcos Renato. 2005.Toda feita: o corpo e o gênero das travestis. Rio de Janeiro: Garamond.

Butler, Judith. 2003.Problemas de Gênero: feminismo e subversão da identidade. Rio de Janeiro: Civilização Brasileira.

Deleuze, Gilles; Parnet, Claire. 1998. Conversações. São Paulo: Editora 34.

Douglas, Mary; Isherwood, Baron. 2004. O Mundo dos bens. Rio de janeiro: Ed. UFRJ.

Fassin, Didier.2012."Toward a critical moral anthropology." In: A companion to moral anthropology. Malden, MA: Wiley-Blackwell.

Gontijo, F; Erick, I. 2015, “Diversidade sexual e de gênero, ruralidade, interioridade e etnicidade no Brasil: ausências, silenciamentos e... exortações". In: Aceno, vol.2, n.4.

Guerra, Verônica Alcântara Guerra. 2015. Sou Salobra: travestilidade, lazer e sociabilidade no Litoral Norte da Paraíba. Dis- sertação de Mestrado. Departamento de Antropologia. Universidade Federal da Paraíba, BRA.

Hardt, Michael; Negri, Antonio. 2000. Empire. Paris; Exils.

Kulick. Don. 2008. Travesti: prostituição, sexo, gênero e cultura no Brasil, Rio de Janeiro: Ed Fiocruz.

Ong, Aihwa. 1999. Flexible citizenship: the cultural logics of transnacionalism. Durham/Londres: Duke University Press.

Lévi-Strauss. A família. 1980. In: Spiro, Melford et al., A família: origem e evolução. Porto Alegre: Editorial Villa Martha.

Patrício, Maria Cecília. 2008. No truque: transnacionalidade e distinção entre travestis brasileiras. Tese de Doutorado, Departamento de Antropologia. Universidade Federal de Pernambuco, BRA

Pelúcio, Larissa. 2009. Abjeção e Desejo: uma etnografia sobre prostituição travesti e o modelo preventivo de Aids. São Paulo: Annablume.

Miller, Daniel. 2004. Pobreza da Moralidade. Antropolítica: Revista Contemporânea de Antropologia e Ciência Política. N.17, p 21-43, 2.

2007. Consumo como

cultura material. Horizontes Antropologicos, vol.13, n.28.

Nascimento, Silvana. 2014. Variações do feminino: circuitos do universo trans na $\mathrm{Pa}$ raíba. In: Revista de Antropologia, vol.57, n.2.

Oliveira. Neuza Maria de. 1994. Damas de paus: o jogo aberto dos travestis no espelho da mulher. Salvador: Centro Editorial e Didático da UFBA.

Parker, Richard G. 2000. Corpos, Prazeres e Paixões: A cultura sexual no Brasil contemporâneo. São Paulo: Editora Best Seller.

Piscitelli, Adriana. 2013. Trânsitos, brasilei- 
ras nos mercados transnacionais do sexo. Rio de Janeiro: Ed Eduerj.

Piscitelli, Adriana. 2008. Interseccionalidades, categorias de articulação e experiênciasde migrantes brasileiras. Sociedade e Cultura, v.11, n.2.

Rubin, Gayle. 1984. Thinking sex: notes for a radical theory on the politcs of sexuality. In: Vance, Carole (Org). Pleasure and danger. Berkeley. California University Press.

Silva, Hélio R.S. 2007. Travestis: entre o espelho e a rua. Rio de Janeiro: Ed. Rocco.

Scott, Russell Parry. 2014. Migracõos interregionais e estratégia doméstica: nordestinos, mobilidade e a casa até os anos 80. Recife: Ed UFPE.

Scott, Russell Parry \& SANTOS, Dayse Amâncio dos [org]. 2013. Novos estudos sobre família e gênero: cotidianos, direitos e performances. Recife: Ed. Universitária da UFPE.

Vale, Alexandre Fleming. C. 2005. O vôo da beleza: travestilidade e devir minoritário. Doutorado em Sociologia. Universidade Federal do Ceará.

Vianna, Adriana. 2001. Direitos, moralidades e desigualdades: Considerações a partir de processos de guarda de crianças. In: Lima, Roberto Kant. Antropologia e Direitos Humanos 3. Niterói: EDUFF.

Recebido entre 24 a 27/02/17

Aprovado em 21/03/17 
